\title{
Leaf Production and Dry Matter Accumulation In Radish (Raphanus sativus L.) to Different Levels of Organic Manures and Inorganic Fertilizer in Sand Regosol
}

\author{
Deshika Viraji M. W. and Brintha Karunarathna*
}

Dept. of Crop Science, Faculty of Agriculture, Eastern University, Sri Lanka

\author{
Corresponding Author \\ Brintha Karunarathna \\ e-mail: ilbrintha@yahoo.co.in
}

\author{
Article History \\ Article ID: IJEP0276 \\ Received in $09^{\text {th }}$ October, 2018 \\ Received in revised form $09^{\text {th }}$ November, 2018 \\ Accepted in final form $21^{\text {st }}$ November, 2018
}

\begin{abstract}
Chemical fertilizers are applied to increase leaf related parameter, but it causes the adverse effect on soil environment and human health. To assess the comparative response of different level of organic manures and inorganic fertilizers on leaf production and dry matter accumulation in radish (Raphanus sativus L.) in Sandy Regosol, field experiment was conducted at the crop farm, Eastern University, Sri Lanka in 2018. The experiment was laid out using Randomized Complete Block Design (RCBD) with seven treatments and four replicates. Treatments were recommended inorganic fertilizer, and $8 \mathrm{t} \mathrm{ha}^{-1}, 6 \mathrm{t} \mathrm{ha}^{-1}, 4 \mathrm{t} \mathrm{ha}^{-1}$ and $2 \mathrm{t} \mathrm{ha}^{-1}$ cow dung with $2 \mathrm{t} \mathrm{ha}{ }^{-1}, 4 \mathrm{tha} \mathrm{h}^{-1}, 6 \mathrm{t} \mathrm{ha} \mathrm{a}^{-1}$ and 8

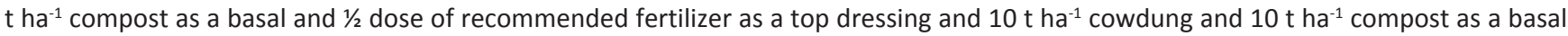
and $1 / 2$ dose of recommended fertilizer as a top dressing. The present study suggested that different levels of cowdung and compost as a basal with half dose of inorganic fertilizer as top dressing gave similar results compared with recommended inorganic fertilizer in leaf development and dry matter accumulation in radish in sandy regosol.
\end{abstract}

Keywords: Compost, cowdung, inorganic fertilizer, radish

\section{Introduction}

Radish (Raphanus sativus L.) is one of the recognized vegetable crops belongs to family Brassicaceae. It is grown and consumed throughout the world as a crunchy salad vegetable (Jilani et al., 2010). The most popular part for eating is the tuberous root although the entire plant is edible and the tops can be used as a leafy vegetable. Over the past $15-20$ years, a lot of effort made to find the better ways to grow crops on sandy soil. Further world population is growing in alarming rate and demand for food is also increasing quickly. Due to an increase in demand for the leafy vegetables as well as their economic reputation, it is very common that excessive doses of inorganic fertilizers are applied to vegetable fields to attain high harvest (Baitilwake et al., 2011). Extreme inorganic fertilizers weaken environmental, ecological sustainability and affect human health and wealth. Therefore replacement of chemical fertilizers by the organic manures or limited chemical fertilizers usage is vital for sustainability of agriculture production for future generation. Increasing soil organic matter is the key to improve cultivation in sandy soil. The organic manure is economically viable and ecologically accepted manure which play a significant role in soil properties. Organic manures feed the soil and maintain sustainability in the agro ecosystem. Application of organic fertilizers to agricultural soils is an important practice for increasing crop yield. It supply micronutrients and improves soil structure, water holding capacity, increase the availability of nutrients as well as change properties of soil suit for cultivation. Objective of this study is to study the comparative response of different levels of organic manures with inorganic fertilizer on leaf production and dry matter accumulation of radish in sandy regosol.

\section{Materials and Methods}

The field experiment was conducted at the crop farm, Eastern University, Sri Lanka in 2018 to assess the comparative response of different level of organic manures and inorganic fertilizers on leaf production and dry matter accumulation in Radish (Raphanus sativus L.) in Sandy Regosol. The experiment was laid out using Randomized Complete Block Design (RCBD) with seven treatments and four replicates. Treatments were recommended inorganic fertilizer $\left(T_{1}\right)$, and $8 \mathrm{t} \mathrm{ha}^{-1}, 6 \mathrm{t} \mathrm{ha}{ }^{-1}, 4 \mathrm{t}$ ha ${ }^{-1}$ and $2 \mathrm{t} \mathrm{ha}^{-1}$ cow dung with $2 \mathrm{t} \mathrm{ha}^{-1}, 4 \mathrm{t} \mathrm{ha}^{-1}, 6 \mathrm{t} \mathrm{ha}^{-1}$ and $8 \mathrm{t}$ $\mathrm{ha}^{-1}$ compost as a basal and $1 / 2$ dose of recommended fertilizer as a top dressing $\left(T_{3}-T_{6}\right)$ and $10 \mathrm{t} \mathrm{ha}^{-1}$ cowdung $\left(T_{2}\right)$ and $10 \mathrm{t} \mathrm{ha}^{-1}$ compost $\left(T_{7}\right)$ as a basal and $1 / 2$ dose of recommended fertilizer as a top dressing. Parameters such as plant height, number of leaves plant ${ }^{-1}$, chlorophyll content in leaf, leaf area, leaf area 
index and dry weight of leaf were recorded and data were analyzed using statistical soft wares.

\section{Results and Discussion}

\subsection{Plant height}

Plant height is a vital part in plant ecological system. It is strongly correlated with life span and time to maturity, and is a major determinant of a species' ability to compete for light (Moles et al., 2009). There was a significant difference $(p<0.01)$ at $2^{\text {nd }}$ and $4^{\text {th }}$ week after planting is shown in Table 1. Tallest seedling was recorded in $T_{2}(10.15 \mathrm{~cm})$ followed

\begin{tabular}{lccc}
\hline \multicolumn{3}{c}{ Table 1: Plant height $(\mathrm{cm})$ of radish at different weeks } \\
\hline Treatments & $\begin{array}{c}2^{\text {nd }} \text { week } \\
\text { after planting }\end{array}$ & $\begin{array}{c}4^{\text {th }} \text { week after } \\
\text { planting }\end{array}$ & $\begin{array}{c}6^{\text {th }} \text { week } \\
\text { after planting }\end{array}$ \\
\hline $\mathrm{T}_{1}$ & $9.65 \pm 0.11^{\mathrm{a}}$ & $16.10 \pm 0.80^{\mathrm{a}}$ & $23.65 \pm 0.80$ \\
$\mathrm{~T}_{2}$ & $10.15 \pm 0.04^{\mathrm{a}}$ & $15.10 \pm 0.42^{\mathrm{a}}$ & $20.63 \pm 0.57$ \\
$\mathrm{~T}_{3}$ & $6.35 \pm 0.04^{\mathrm{d}}$ & $12.60 \pm 0.52^{\mathrm{bc}}$ & $20.33 \pm 1.08$ \\
$\mathrm{~T}_{4}$ & $7.55 \pm 0.18^{\mathrm{c}}$ & $15.41 \pm 0.92^{\mathrm{a}}$ & $22.38 \pm 0.67$ \\
$\mathrm{~T}_{5}$ & $8.75 \pm 0.32^{\mathrm{b}}$ & $16.58 \pm 0.75^{\mathrm{a}}$ & $22.17 \pm 0.94$ \\
$\mathrm{~T}_{6}$ & $8.00 \pm 0.07^{\mathrm{c}}$ & $14.60 \pm 0.44^{\mathrm{ab}}$ & $21.27 \pm 1.57$ \\
$\mathrm{~T}_{7}$ & $8.55 \pm 0.18^{\mathrm{b}}$ & $11.63 \pm 1.03^{\mathrm{c}}$ & $22.30 \pm 1.07$ \\
$\mathrm{~F}_{\text {test }}$ & $* *$ & $* *$ & $\mathrm{~ns}$ \\
\hline
\end{tabular}

Value represent mean \pm standard error of four replicates; $F$ test: ${ }^{* *}: p<0.01$; ns: not significant; Means followed by the same letter in each column are not significantly different according to the Duncan's multiple range test at $5 \%$ level

by $T_{1}(9.65 \mathrm{~cm})$ while shortest seedlings were recorded in $T_{3}$ $(6.35 \mathrm{~cm})$ at $2^{\text {nd }}$ week after planting. At $4^{\text {th }}$ week after planting, average plant height ranged from $16.58 \mathrm{~cm}\left(T_{5}\right)$ to $11.63 \mathrm{~cm}$ (T7). However, $T_{1}, T_{2}, T_{4}, T_{5}$ and $T_{6}$ were statistically same in plant height at $4^{\text {th }}$ week after planting. There was no significant difference $(p>0.05)$ in plant height at $6^{\text {th }}$ week after planting. It is agreeable with the findings of Eric (2016) stated that radish plant height was not significantly differ $(p>0.05)$ when apply the vermicast at the rates from $5 \mathrm{t} \mathrm{ha}^{-1}$ to $20 \mathrm{t} \mathrm{ha}^{-1}$.

\subsection{No. of leaves plants ${ }^{-1}$}

Instead of large physical dimensions of the sources, optimum and more stable functional efficiency at moderate source size are more advantageous to realize the potential sink size under field conditions (Islam et al., 2016). Crop growth relies on photosynthesis and the growth rate directly reveal photosynthetic rate (Evans, 2013). Shoot growth and leaf production is an vital process which affect yield of crops. Number of leaves per plant at weekly interval is shown in Table 2. Combination of organic manures and or inorganic fertilizer which have not been significantly affected the number of leaves $2^{\text {nd }}$ and $6^{\text {th }}$ weeks after planting is confirmed with $\mathrm{P}$ values 0.399 and 0.176 and chi square values of 6.22 and 8.96 respectively. Similar findings were noted by Asgar et al. (2006)

\begin{tabular}{lccc}
\hline \multicolumn{4}{c}{ Table 2: Number of leaves per radish plant at different weeks } \\
\hline Treatments & $\begin{array}{c}2^{\text {nd }} \text { week } \\
\text { after planting }\end{array}$ & $\begin{array}{c}4^{\text {th }} \text { week after } \\
\text { planting }\end{array}$ & $\begin{array}{c}6^{\text {th }} \text { week } \\
\text { after planting }\end{array}$ \\
\hline $\mathrm{T}_{1}$ & 5 & 9 & 16 \\
$\mathrm{~T}_{2}$ & 5 & 10 & 14 \\
$\mathrm{~T}_{3}$ & 5 & 8 & 17 \\
$\mathrm{~T}_{4}$ & 5 & 9 & 15 \\
$\mathrm{~T}_{5}$ & 5 & 10 & 16 \\
$\mathrm{~T}_{6}$ & 5 & 9 & 16 \\
$\mathrm{~T}_{7}$ & 5 & 8 & 13 \\
$p$ value & 0.399 & 0.021 & 0.176 \\
Chi square & 6.22 & 14.93 & 8.96 \\
\hline
\end{tabular}

stated that number of leaves was observed statistically same in recommended nitrogen fertilizer and in the treatments where enriched compost was applied in integration with different levels of chemical fertilizer.

\subsection{Chlorophyll content}

Chlorophyll in leaf is a useful parameter which used to detect nitrogen deficiencies (Blackmer and Schepers, 1995) and helps to maintain healthy plants. Also positive association between photosynthetic rate and chlorophyll content was reported by Nagaraj et al. (2002). Significant difference $(p<0.01)$ was observed at $2^{\text {nd }}$ weeks after planting. It was high in $\mathrm{T}_{3}$ followed by $T_{6}$, while low in $T_{1}$. The result is agreeable with Ghosh et al. (2004) stated that total chlorophyll content was higher in organically treated plots than that in $100 \%$ NPK. However, there was no significant difference $(p>0.05)$ in chlorophyll content of leaves at $4^{\text {th }}$ and $6^{\text {th }}$ week after planting is shown in Table 3.

\begin{tabular}{lccc}
\hline \multicolumn{3}{c}{ Table 3: Chlorophyll content of radish at different week } \\
\hline Treatments & $\begin{array}{c}2^{\text {nd }} \text { week } \\
\text { after planting }\end{array}$ & $\begin{array}{c}4^{\text {th }} \text { week after } \\
\text { planting }\end{array}$ & $\begin{array}{c}6^{\text {th }} \text { week } \\
\text { after planting }\end{array}$ \\
\hline $\mathrm{T}_{1}$ & $34.70 \pm 0.42^{\mathrm{g}}$ & $47.81 \pm 1.25$ & $47.67 \pm 1.28$ \\
$\mathrm{~T}_{2}$ & $39.05 \pm 0.74^{\mathrm{d}}$ & $44.29 \pm 2.37$ & $45.45 \pm 1.17$ \\
$\mathrm{~T}_{3}$ & $43.65 \pm 0.39^{\mathrm{a}}$ & $45.93 \pm 1.06$ & $46.57 \pm 1.95$ \\
$\mathrm{~T}_{4}$ & $39.70 \pm 0.42^{\mathrm{c}}$ & $45.98 \pm 1.93$ & $44.86 \pm 1.08$ \\
$\mathrm{~T}_{5}$ & $37.25 \pm 0.88^{\mathrm{f}}$ & $47.05 \pm 2.82$ & $47.60 \pm 2.34$ \\
$\mathrm{~T}_{6}$ & $43.05 \pm 0.39^{\mathrm{b}}$ & $43.33 \pm 1.79$ & $48.98 \pm 0.68$ \\
$\mathrm{~T}_{7}$ & $38.95 \pm 0.18^{\mathrm{e}}$ & $43.38 \pm 1.22$ & $48.92 \pm 1.87$ \\
$\mathrm{~F}$ value & $* *$ & $\mathrm{~ns}$ & $\mathrm{~ns}$ \\
\hline
\end{tabular}

Value represent mean \pm standard error of four replicates; $F$ test: **: $p<0.01$; ns: not significant; Means followed by the same letter in each column are not significantly different according to the Duncan's multiple range test at 5\% level

\subsection{Leaf area}

Leaf area is a vital variable in models for predicting crop 
growth and dry matter production in agriculture. The reduction of growth is often accompanied by reduction of photosynthetic pigments and lower photosynthetic rate and it is largely attributed to the reduction in light interception due the reduced leaf area. Leaf area influences the interception and utilization of solar radiation of crop and consequently, the dry matter production (Boote et al., 1998). Photosynthetic light absorption, carbon uptake and assimilation, transpiration of water and emission of volatile organic compounds are nearly exclusively performed via leaf surfaces (Fleck et al., 2009). The leaf area of tested treatments is given in Table 4. There was significant difference in leaf area at $2^{\text {nd }}(p<0.05)$ and $4^{\text {th }}(p<0.01)$ weeks after planting. At $4^{\text {th }}$ weeks after planting the maximum value of $435.18 \mathrm{~cm}^{2}$ was recorded in $T_{1}$ followed by $T_{5}\left(321.65 \mathrm{~cm}^{2}\right)$. Maximum leaf area in $T_{1}$ may be the reason for applied full dose of topdressing at $3^{\text {rd }}$ week to the $T_{1}$ and $1 / 2$ dose for other treatments. However no significant in leaf area was noted at $6^{\text {th }}$ week after planting. Leaf area estimates and the quantity of photo synthetically active radiation captured by plant canopies are required in evapotranspiration and crop yield models (Asrar et al., 1984).

\begin{tabular}{lccc}
\hline \multicolumn{4}{l}{ Table 4: Leaf area of radish at different week } \\
\hline $\begin{array}{l}\text { Treat- } \\
\text { ments }\end{array}$ & $\begin{array}{c}2^{\text {nd }} \text { week after } \\
\text { planting }\end{array}$ & $\begin{array}{c}4^{\text {th }} \text { week after } \\
\text { planting }\end{array}$ & $\begin{array}{c}6^{\text {th }} \text { week after } \\
\text { planting }\end{array}$ \\
\hline $\mathrm{T}_{1}$ & $23.89 \pm 1.69^{\text {ab }}$ & $435.18 \pm 7.26^{\mathrm{a}}$ & $785.16 \pm 71.08$ \\
$\mathrm{~T}_{2}$ & $26.27 \pm 0.98^{\mathrm{a}}$ & $283.12 \pm 9.04^{\mathrm{c}}$ & $1317.04 \pm 308.18$ \\
$\mathrm{~T}_{3}$ & $17.98 \pm 1.32^{\mathrm{c}}$ & $176.25 \pm 4.27^{\mathrm{e}}$ & $1287.74 \pm 215.47$ \\
$\mathrm{~T}_{4}$ & $24.94 \pm 1.38^{\text {ab }}$ & $209.30 \pm 3.58^{\mathrm{d}}$ & $1407.44 \pm 246.81$ \\
$\mathrm{~T}_{5}$ & $26.21 \pm 1.33^{\mathrm{a}}$ & $321.65 \pm 4.53^{\mathrm{b}}$ & $1235.66 \pm 256.90$ \\
$\mathrm{~T}_{6}$ & $22.58 \pm 1.03^{\text {abc }}$ & $263.713 \pm 6.73^{\mathrm{c}}$ & $1080.36 \pm 177.83$ \\
$\mathrm{~T}_{7}$ & $20.68 \pm 0.97^{\text {bc }}$ & $158.45 \pm 5.53^{\mathrm{f}}$ & $1077.55 \pm 378.21$ \\
$\mathrm{~F}$ value & $*$ & $* *$ & $\mathrm{~ns}$ \\
\hline
\end{tabular}

Value represent mean \pm standard error of four replicates; $F$ test: ${ }^{* *}: p<0.01$; ns: not significant; Means followed by the same letter in each column are not significantly different according to the Duncan's multiple range test at $5 \%$ level

\subsection{Leaf area index (LAI)}

LAl is an important structural property of vegetation. Because leaf surfaces are the primary border of energy and mass exchange, canopy interception, evapotranspiration, and gross photosynthesis are directly proportional to LAI. LAI of tested treatments is given in Table 5. At $2^{\text {nd }}$ week after planting, maximum of $0.612\left(T_{7}\right)$ and minimum of $0.81\left(T_{2}\right)$ were noted. As regards to $4^{\text {th }}$ week after planting leaf area index in $\mathrm{T}_{1}$ was maximum (0.538) and minimum in $\mathrm{T}_{4}(0.267)$. No significant differences among tested treatment in LAl at $6^{\text {th }}$ week after planting.

\subsection{Dry weight of leaves}

There is a significantly different $(p<0.05)$ among tested

\begin{tabular}{lccc}
\hline \multicolumn{4}{l}{ Table 5: Leaf area index of radish at different week } \\
\hline $\begin{array}{l}\text { Treat- } \\
\text { ments }\end{array}$ & $\begin{array}{c}2^{\text {nd }} \text { week after } \\
\text { planting }\end{array}$ & $\begin{array}{c}4^{\text {th }} \text { week after } \\
\text { planting }\end{array}$ & $\begin{array}{c}6^{\text {th }} \text { week after } \\
\text { planting }\end{array}$ \\
\hline $\mathrm{T}_{1}$ & $0.085 \pm 0.043^{\mathrm{b}}$ & $0.538 \pm 0.042^{\mathrm{a}}$ & $0.69 \pm 0.09$ \\
$\mathrm{~T}_{2}$ & $0.081 \pm 0.003^{\mathrm{b}}$ & $0.368 \pm 0.045^{\mathrm{b}}$ & $0.97 \pm 0.21$ \\
$\mathrm{~T}_{3}$ & $0.125 \pm 0.003^{\mathrm{b}}$ & $0.357 \pm 0.035^{\mathrm{b}}$ & $1.15 \pm 0.22$ \\
$\mathrm{~T}_{4}$ & $0.153 \pm 0.005^{\mathrm{b}}$ & $0.267 \pm 0.060^{\mathrm{c}}$ & $0.94 \pm 0.20$ \\
$\mathrm{~T}_{5}$ & $0.127 \pm 0.004^{\mathrm{b}}$ & $0.369 \pm 0.060^{\mathrm{b}}$ & $0.82 \pm 0.10$ \\
$\mathrm{~T}_{6}$ & $0.114 \pm 0.005^{\mathrm{b}}$ & $0.370 \pm 0.060^{\mathrm{b}}$ & $0.85 \pm 0.11$ \\
$\mathrm{~T}_{7}$ & $0.612 \pm 0.234^{\mathrm{a}}$ & $0.377 \pm 0.053^{\mathrm{b}}$ & $0.82 \pm 0.10$ \\
$\mathrm{~F}_{\text {value }}$ & $*$ & $* *$ & $\mathrm{~ns}$ \\
\hline
\end{tabular}

Value represent mean \pm standard error of four replicates; $F$ test: ${ }^{* *}: p<0.01$; ns: not significant; Means followed by the same letter in each column are not significantly different according to the Duncan's multiple range test at $5 \%$ level

treatment in leaves dry weight at $2^{\text {nd }}$ and $4^{\text {th }}$ week after planting is shown in Table 6. Highest leaves dry weight was recorded in $T_{1}(2.02 \mathrm{~g})$ followed by $T_{5}(1.83 \mathrm{~g})$ at $4^{\text {th }}$ week after planting. However, no significant differences $(p>0.05)$ was noted at $6^{\text {th }}$ week after planting. In contrast to this study, Priyadarshani et al. (2013) stated that both compost and inorganic fertilizer treatments had significant effect on the shoot and root dry weights.

\begin{tabular}{lccc}
\hline \multicolumn{4}{l}{ Table 6: Leaves dry weight of radish at different weeks } \\
ments & $\begin{array}{c}2^{\text {nd }} \text { week after } \\
\text { planting }\end{array}$ & $\begin{array}{c}4^{\text {th }} \text { week after } \\
\text { planting }\end{array}$ & $\begin{array}{c}6^{\text {th }} \text { week after } \\
\text { planting }\end{array}$ \\
\hline $\mathrm{T}_{1}$ & $0.16 \pm 0.030^{\text {ab }}$ & $2.02 \pm 0.45^{\mathrm{a}}$ & $6.53 \pm 0.40$ \\
$\mathrm{~T}_{2}$ & $0.21 \pm 0.006^{\mathrm{a}}$ & $1.37 \pm 0.30^{\text {abc }}$ & $6.00 \pm 1.40$ \\
$\mathrm{~T}_{3}$ & $0.10 \pm 0.004^{\mathrm{b}}$ & $0.68 \pm 0.06^{\mathrm{c}}$ & $4.96 \pm 0.50$ \\
$\mathrm{~T}_{4}$ & $0.17 \pm 0.010^{\mathrm{ab}}$ & $1.15 \pm 0.18^{\text {bc }}$ & $5.41 \pm 0.40$ \\
$\mathrm{~T}_{5}$ & $0.16 \pm 0.010^{\mathrm{ab}}$ & $1.83 \pm 0.24^{\text {ab }}$ & $5.19 \pm 0.32$ \\
$\mathrm{~T}_{6}$ & $0.14 \pm 0.020^{\mathrm{ab}}$ & $0.81 \pm 0.08^{\mathrm{c}}$ & $5.58 \pm 0.67$ \\
$\mathrm{~T}_{7}$ & $0.11 \pm 0.011^{\mathrm{b}}$ & $0.68 \pm 0.15^{\mathrm{c}}$ & $4.66 \pm 0.61$ \\
F value & $*$ & $* *$ & $\mathrm{~ns}$ \\
\hline
\end{tabular}

Value represent mean \pm standard error of four replicates; $F$ test: ${ }^{* *}: p<0.01$; ns: not significant; Means followed by the same letter in each column are not significantly different according to the Duncan's multiple range test at $5 \%$ level

\section{Conclusion}

Plant height, number of leaves, chlorophyll content, leaf area, leaf area index and dry weight of leaves were not significantly differ among the tested treatments at $6^{\text {th }}$ week after planting. Different levels of cowdung and compost as a basal with half dose of inorganic fertilizer as top dressing gave similar results compared with recommended inorganic fertilizer. And there is possibility to reduce the use of inorganic fertilizer without 
affecting the leaf development and dry matter accumulation in radish in sandy regosol.

\section{References}

Asghar, H.N., Ishaq, M., Zahir, Z., Khalid, Z., Arshad, M., 2006. Response of radish to integrated use of nitrogen fertilizer and recycled organic waste. Pakistan Journal of Botany 38(3), 691-700.

Asrar, G., Fuchs, M., Kanemasu, E., Hatfield, J., 1984. Estimating Absorbed Photosynthetic Radiation and Leaf Area Index from Spectral Reflectance in Wheat. Agronomy Journal 76, 300-306.

Baitilwake, M.A., De Bolle, S., Salomez, J., Mrema, J.P., Neve, S. De., 2011. Effect of Manure nitrogen on vegetables' yield and nitrogen efficiency in Tanzania. International Journal of Plant Production 5(4), 417-429.

Blackmer, T.M., Schepers, J.S., 1995. Use of a Chlorophyll Meter to Monitor Nitrogen Status and Schedule Fertigation for Corn. Journal of Production Agriculture $8(1), 56-60$.

Boote, K.J., Jones, J.W., Hoogenboom, G., 1998. Simulation of crop growth CROPGRO model. In: RM Peart and R Curry, Editors, Agricultural Systems Modeling and Simulation, Marcel Dekker Inc, New York, USA, 651-692.

Eric, R., Politud, R., 2016. Growth and Yield Performance of Radish (Raphanus sativus L.) 'cv' 'SNOW WHITE' in Response to Varying Levels of Vermicast Applications. International Journal of Scientific and Research Publications 6(5), 53-57.

Fleck, S., Raspe, S., Cater, M., Schleppi, P., 2009/2010. Manual on methods andcriteria for harmonized sampling,assessment,monitoring and analysis of the effects of air pollution on forests. Manual Part xvii,Leaf area Measurements, 37.

Ghosh, P.K., Ajay Bandyopadhyay, K.K., Manna, M.C., Mandal, K.G., Misra, A.K., Hati, K.M., 2004. Comparative effectiveness of cattle manure, poultry manure, phosphocompost and fertilizer-NPK on three cropping systems in vertisols of semi-arid tropics. II. Dry matter yield, nodulation, chlorophyll content and enzyme activity. Bioresource technology 95(1), 85-93.

Islam, A.F.M.S., Md. Haque, M., Tabassum, R., Md. Islam, M., 2016. Effect of Defoliation on Growth and Yield Response in Two Tomato (Solanum lycopersicum Mill.) Varieties. Journal of Agronomy 15(2), 68-75.

Jilani, M.S., Burki, T., Waseem, K., 2010. Effect of nitrogen on growth and yield of radish. Journal of Agricultural Research 48(2), 219-225.

John Evans, R., 2013. Improving Photosynthesis. Plant physiology 162(4), 1780-1793.

Moles, A.T., Warton, D.I., Warman, L., Swenson, N.G., Laffan, S.W., Zanne, A.E., Pitman, A., Hemmings, F.A., Leishman, M.R., 2009. Global patterns in plant height. Journal of Ecology 97, 923-932.

Nagaraj, N., Reese, J.C., Kirkham, M.B., Kofoid, K., 2002. Relationship between chlorophyll loss and photosynthetic rate in Greenbug (Homoptera:Aphididae) damaged sorghum. Journal of the Kansas Entomological Society 75, 101-109.

Priyadarshani, N.D.N., Amarasinghe, M.K.T.K., Subasinghe, S., Palihakkara, I.R., Kumarasinghe, H.K.M.S., 2013. Effect of organic and inorganic fertilizers on biomass production, oil yield and quality of vetiver (Vetiveria zizanioides L.). Journal of Agricultural Sciences 8(1), 28-35. 